\title{
Implementing Municipal Tree Planting: Los Angeles Million-Tree Initiative
}

\author{
Stephanie Pincetl
}

Received: 13 January 2009/ Accepted: 22 November 2009/Published online: 17 December 2009

(C) The Author(s) 2009. This article is published with open access at Springerlink.com

\begin{abstract}
Urban forests are increasingly being seen as an important infrastructure that can help cities remediate their environmental impacts. This work reports on the first steps in implementing a million tree program in Los Angeles and the ways such a biogenic_living_infrastructure has been approached. Numbers of studies have been done to quantify the benefits of urban forests, but little has been written on the process of implementing urban tree planting programs. The investigative methods were primarily qualitative, involving interviews, attending meetings and conducting literature reviews. Results indicate that multiple nonprofit and city agency programs are involved in planting and maintaining trees and this has required coordination among groups that here-to-fore were unaccustomed to having to collaborate. The main finding that emerge from this research is that the implementation of such a program in Los Angeles is more complicated than it may seem due to several interacting factors: the need to rely on multiple public and private organizations to put trees into the ground and to maintain them; coordination of these multiple efforts must be centralized, but requires a great deal of time and effort and maybe resisted by some of the partners; funding for planting and long term maintenance must be pieced together from multiple sources; acceptance of trees by residents varies by neighborhood as does tree canopy cover; appropriate nursery supply can be limited; thelocation of the program within the
\end{abstract}

S. Pincetl $(\bowtie)$

UCLA, Institute of the Environment, 619 Chales E. Young

Drive, East Los Angeles, CA 90095, USA

e-mail: spincetl@ioe.ucla.edu

S. Pincetl

US Forest Service, Pacific Southwest Research Station, 4955 Canyon Crest Drive, Riverside, CA 92507, USA city administration is determined by who initiates the program.

Keywords Urban forestry - Implementation - Biogenic Infrastructure $\cdot$ Governance $\cdot$ Urban environment

\section{Introduction}

For the first time in human history, more than half the world's population is residing in cities (Cohen 2003). Most global and regional environmental problems originate in cities as cities concentrate increasing numbers of people and human activities, exporting emissions and waste (Alberti and Susskind 1996). With greater understanding of the effects of fossil fuel consumption on climate change and atmospheric pollution, there has been growing interest in urban forests as they are purported to provide many benefits, including temperature modification and energy conservation, abatement of air and water pollution, and enhanced property values (Geoghegan and others 1997; Tyrvainen 1997; Scott and others 1998; McPherson and others 1999; Iverson and Cook 2000; Brack 2002; Mansfield and others 2005; Nowak and others 2006a, b, c). For example, the urban forest of Washington, D.C., is estimated to store about 526,000 tons of carbon and to remove about 540 tons of air pollution a year (Nowak 2006a); the urban forest in Casper, Wyoming, is estimated to store about 37,000 tons of carbon and to remove about 50 tons of air pollution per year (Nowak 2006b). Such estimations are increasingly being commissioned from the U.S. Forest Service by cities around the country as well as by other researchers, to justify expanding existing urban forests. The research stations of the U.S. Forest Service have published extensively on the value and functions of urban trees, 
alongside more traditional forest-related research and publications (see the U.S. Forest Service publications Web site at http://www.na.fs.fed.us/pubs/).

As a result, some cities, such as Los Angeles and New York, have the goal of adding a million more trees to their existing forests. Even the National Conference of Mayors has highlighted the importance of urban trees by hosting, since 2006, an awards event honoring cities with innovative urban forestry programs, at which the Home Depot Foundation has been giving winners up to $\$ 200,000$ in grant funds (see http://www.homedepotfoundation.org/ grantees.htm). Los Angeles is the second largest city in the United States and the densest metropolitan region in the country (Fulton and others 2001; Harden 2005). The region continues to struggle with high rates of air and water pollution, and climate predictions show that the region will most likely become warmer and drier (California Energy Commission 2006). Strategies to improve the city's environmental management to reduce the city's pollution, ecological footprint, and carbon footprint have been at the political forefront for the past several years.

Los Angeles mayor Villaraigosa ran on a green platform in 2005 and appointed a significant number of well-known local environmentalists to his staff and to city boards and commissions. Among his campaign pledges was to make Los Angeles the greenest city in the nation and to plant a million more trees. The idea of planting trees to improve the environment in Los Angeles is not new. In 1984, for the Los Angeles-hosted Olympic Summer Games, TreePeople, a local nonprofit, planted a million trees, including in the nearby mountains (Moll and Ebenreck 1989) (see http:// www.treepeople.org/). Planting trees has become an increasingly popular idea across the country, and even abroad, as a means of urban environmental remediation and enhancement of human well-being (Landsberg 1981; Rowntree and Nowak 1991; McPherson and Rowntree 1993; Attwell 2000; Coles and Bussey 2000; Li and others 2005).

Los Angeles commissioned Greg McPherson at the Center for Urban Forest Research (CUFR) of the U.S. Forest Service's Pacific Southwest Research Station to assess the possibilities of planting a million more trees in the existing urban fabric and the potential effects of expanding the city's tree canopy cover by one million more trees. The CUFR identified the areas in Los Angeles that could accommodate the desired trees and estimated that forest benefits would include over $\$ 1$ billion in aesthetic and other benefits: \$75-117 million in energy savings, \$53-83 million in air quality improvements, \$5.1-8.3 million in carbon dioxide reductions, and \$97-153 million in stormwater interception. Total benefits were estimated to be from $\$ 1.3$ to $\$ 2.0$ billion in total a year. This amounts to \$49-60 per tree per year (McPherson and others 2008). Studies from different parts of the country show that urban benefits from urban forestry vary as they are climate- and region-contingent. The U.S. Forest Service research stations provide extensive bibliographies of many dozens of research articles on specific aspects of benefits from trees in cities (http://www.na.fs.fed.U.S./pubs/).

Though a number of studies have examined the various environmental benefits of urban forests, little research has been conducted describing the process of implementing large-scale urban forestry. This article reports preliminary findings on the ways in which the city approached the implementation of this new program. The research is part of an interdisciplinary research project funded by the National Science Foundation to investigate the coupled biosocial aspects of implementing an afforestation program in Los Angeles, California.

The objective of this article is to explore and elucidate the challenges facing cities in institutionalizing a new kind of infrastructure-namely, a living forest-through a specific case study. We detail the process undertaken by the second largest city, examine some of the difficulties encountered along the way, and attempt to place this program in a larger framework of new program creation.

Examining the process of implementation of a new environmental initiative like the Million Trees Los Angeles (MTLA) program provides insight to the issues that face municipalities in the United States in developing their own programs to ameliorate environmental pollution and improve quality of life. The research highlights some of the common structural issues that will likely face most cities such as governmental transformations that increasingly include new nongovernmental partners and alternative sources of funding to accomplish goals (Salamon 2002). This creates a shift from government to governance, with the government assuming a coordinating role (Jessop 1998).

\section{Study Area}

The city of Los Angeles encompasses over $1,223 \mathrm{~km}^{2}$. Over $15 \%$ of the land area consists of naturally vegetated mountains. Los Angeles's existing tree canopy cover is $21 \%$, which compares favorably to $20 \%$ in Baltimore and $23 \%$ in New York City (McPherson and others 2008). Cover ranges from $7 \%$ to $37 \%$ per council district (McPherson and others 2008). The region is characterized by a Mediterranean climate with long, hot summers and moderate winter precipitation, including snow at the upper elevations. Precipitation averages $38 \mathrm{~cm}$ of rain a year, typically falling between January and March. The dominant Southern California vegetation type is chaparral. There is variation in chaparral type, depending on whether the exposure is north or south facing, and forested areas are in higher elevations in the mountains. Before urbanization, oak woodlands were 
formerly found in moist sites with deep slopes in canyon bottoms and north-facing slopes. Oak savannah also existed in the mountain foothills, but none persists in the area today (Schoenherr 1992). There is some scholarly disagreement about whether chaparral dominated the landscape or whether there were oak savannas in some of the valleys-the historical record is quite patchy-but by the beginning of the 20 th century, no native forests were extant. Since urbanization, many nonnative trees have been planted, and the urban landscape is largely an anthropogenic creation.

\section{Theory and Methods}

The methods employed to understand why and how MTLA came about and how the program was implemented were informed by critical realist philosophy (Sayer 2000). Realism provides an ontological and epistemological basis for understanding causality (Drummond and Marsden 1999). Critical realism starts with the premise that social systems are open, evolve, and are messy and ambiguous. At the same time, this does not mean abandoning explanation. Sayer (2000) suggests that (1) explanation depends on identifying causal mechanisms and how they work, discovering if they have been activated and under what conditions (Sayer 2000), and (2) the social world can produce different outcomes due to local conditions as events are not predetermined before they happen, but rather, depend on contingent conditions. This means that the future is open and things could go many different ways (Sayer 2000). Therefore explanation requires interpretive and qualitative research to discover actors' reasoning and circumstances in specific contexts-not in abstraction from them (Sayer 2000).

Figure 1 shows how structure intersects with conditions to create effects or events. Meaningful lessons can be drawn from those experiences that can inform how other contexts are approached and analyzed, but each place will

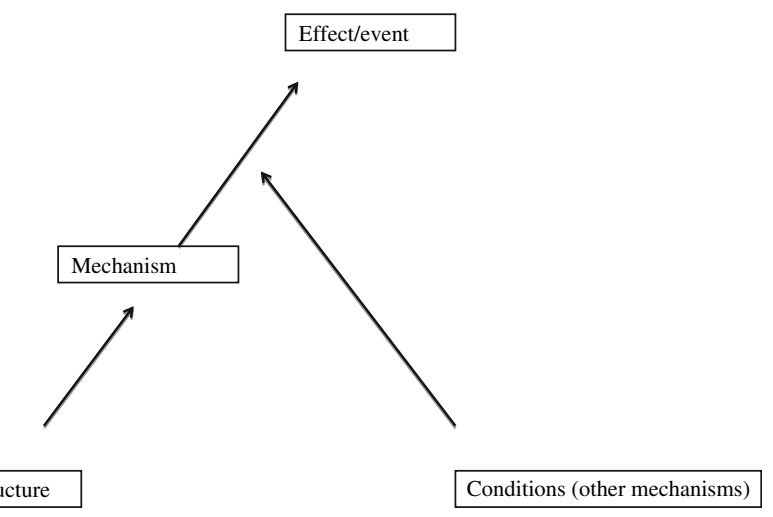

Fig. 1 Critical realist view of causation (Sayer 2000, p. 15) exhibit its own specificities, and the experiences may or may not be generalizable. For example, New York City has also established a Million Tree planting initiative for many of the same environmental reasons as Los Angeles, but its approach is different than that of Los Angeles because of New York's greater ability to raise funds, and Million Trees Houston is different yet. New York City, over time, has raised property taxes to achieve multiple city goals; the city of Los Angeles, because of citizen initiatives requiring two-thirds majority vote for new taxes, cannot do so, and Houston has established an entirely private campaign to plant a million trees. Each approach emerges from historic cultures of government and governance in the different regions of the country. While the goal of planting a million trees, and the reasons for doing so, may be similar, each program organization is markedly different. As González and Healy (2005) note, an action that may promote socially innovative initiatives in one context may produce different ones in another (Fig. 1).

We also draw on Jessop's $(1994,1999,2000)$ theoretical work on the state and governance in analyzing how the city of Los Angeles has organized its program. Jessop argues that post-Fordism has intensified societal complexity because of a greater differentiation of institutional orders and a widening and deepening of systemic interdependencies across various social, spatial, and temporal horizons of action and time-space scales (Jessop 1994). He argues that there is now a strong emphasis on partnership and networks rather than top-down national government. Thus, in addition to subsidiarity and solidarity across different scales of economic, political, and social organization, in many places, there is an increased reliance on partnerships between the public and private sectors and between government and civil society (Jessop 1994). Such reliance requires interdependent self-organizing of multiple actors, each with divergent internal systems of organization, to develop ways of working together on overlapping goals. This form of governance is described as heterarchic, or self-organizing (Miller and others 2007), with the state operating as the coordinator of these different actors, setting the conditions for participation. As Jessop explains, this reflects the paradox that a limited state can be a strong state even when its purpose becomes to steer partnerships and to moderate them in the interests of "the maximum welfare of all the people" (Jessop 2000, p 5).

Theories of governance and the role of the state emphasize the role of government in coordinating the actions of multiple partners and in cooperating with them (Pierre 2000; Jordon and others 2003). The state sustains coherence and continuity among the partners through relationships of trust among the actors (or some reasonable amount of trust) and of state-reinforced interdependence (Fig. 2). 




Fig. 2 Heterarchic governance

To understand and explain the process of implementation of this new program in Los Angeles, several qualitative techniques of inquiry were utilized:

1. interviewing key actors involved in the implementation of the program (see Table 1 for categories of interviewees and their roles)

2. attending meetings and hearings

3. reading official and unofficial texts and newspaper accounts
4. gathering information about funding and numbers of trees planted from disparate sources, including interviewees, the MTLA Web site, and news articles

Open-ended interviews with over 20 program participants of 1 hour or more were conducted from 2005 to 2008, including with government officials, nongovernmental organizations (NGOs), consultants, and advisors. Interviews were based on a common University of California, Los Angeles Institutional Review Board-approved interview protocol for each type of participant (government, NGO, consultant, or advisor). Categories of questions included involvement and activities with the program, interviewee perception of the goals of the program, obstacles and impediments the interviewee faced, and the opportunities they saw in the program. Questions also probed funding levels and sources, long- and short-term

Table 1 Network of partners participating directly and indirectly in the Million Tree Los Angeles Program

\begin{tabular}{|c|c|}
\hline Million tree participants & Involvement \\
\hline \multicolumn{2}{|l|}{ City Agencies } \\
\hline Mayor's Office (appointed Officials) & $\begin{array}{l}\text { Directs and coordinates program } \\
\text { Finds funding } \\
\text { Contracts with tree planting partners } \\
\text { Monitors program implementation including tree numbers and locations }\end{array}$ \\
\hline $\begin{array}{l}\text { Department of Public Works, Urban } \\
\text { Forestry Department }\end{array}$ & $\begin{array}{l}\text { Establishes official street tree list } \\
\text { Inspects trees to be purchased } \\
\text { Inspects proposed street tree planting locations and whether trees have } \\
\text { been planted correctly } \\
\text { Conducts tree pruning }\end{array}$ \\
\hline Department of Public Works Appointed Commission & Oversees Million Tree Foundation \\
\hline Department of Water and Power & Funds tree purchases under Trees for a Green Los Angeles Program \\
\hline Department of Environmental Affairs & $\begin{array}{l}\text { Assists in grant writing to fund program } \\
\text { Keeps track of tree planting numbers }\end{array}$ \\
\hline Department of Recreation and Parks & Plants trees that count toward the one million tree program count \\
\hline Community Redevelopment Agency & $\begin{array}{l}\text { Requires trees to be planted in all projects } \\
\text { Applies for Federal Community Development Block Grant funds for tree } \\
\text { planting and funds nonprofits to implement tree planting in the project areas }\end{array}$ \\
\hline Port of Los Angeles & Conducts own program of tree planting that is counted in Million Tree Program \\
\hline NonProfit Organizations & $\begin{array}{l}\text { Plant street trees by Council District determined by the mayor's appointed } \\
\text { Director of the Program } \\
\text { Write grants to support tree planting } \\
\text { Solicit permission to plant in the Council District, parcel by parcel } \\
\text { Conduct tree give away even events } \\
\text { Conduct tree planting events at schools and other public locations } \\
\text { Work with Business Improvement Districts to plant trees in business areas } \\
\text { Conduct tree planting in parks } \\
\text { Employ youth to plant trees (job creation) }\end{array}$ \\
\hline State of California & Cal Fire agency provides grants to nonprofits and city for tree planting \\
\hline Private Sector & $\begin{array}{l}\text { Political consultants to Mayor suggest Million Tree Program as a platform } \\
\text { for mayoral campaign } \\
\text { Consult on implementation plan and framework }\end{array}$ \\
\hline
\end{tabular}


goals, and changes they would like to see or had experienced. The answers are not quantifiable but provide significant information about the genesis (or causal mechanisms) of the program, choices made for its implementation, and the roles of different participants (Table 1).

A number of the participants were interviewed at least twice, with follow-up questions and/or updates. Each major interview was transcribed and sent to the interviewee for changes and approval.

The author also served as a member of the steering committee when the program was initiated, and the analysis of the early evolution of the program is informed by this participation. Participation provided unique interpretive understanding that would have been difficult to obtain without immersion in the initial discussions and interactions. For example, under the original leadership of the program in the Public Works Commission, meetings were frequent, and information was broadly shared among participants, including prospective nonprofit organizations that would be planting the trees and city agencies. Tree selection criteria were debated to ensure that trees appropriate for the Los Angeles Mediterranean climate were selected for the new program. It was acknowledged that there needed to be outreach to growers to encourage the development of more climate-appropriate nursery stock as, under current conditions, there were insufficient appropriate trees being supplied by the nursery industry. There was a great deal of discussion about developing a plan to prioritize areas in the city where trees should first be planted. Other topics of interest included how (and if) the city should be divided up among the tree-planting nonprofits, methodologies to monitor the effectiveness of the program relative to its goal of improving urban environmental quality, and funding.

When the program was moved into the Mayor's Office, meetings of collaborators were only rarely held; rather, the specific collaborating partners were contacted individually by the new director for specific implementation issues. Researchers were no longer invited to any meetings but were able to conduct interviews with the director to learn of the program's progress. Information was tightly controlled by the new director, demonstrating Jessop's (1999) observation that a limited state can still be a strong state. Initiatives such as outreach to tree growers were not undertaken, nor was there the development of a citywide tree-planting roll-out plan with targeted priority areas and species of trees.

\section{How the Program Came About and Was Implemented}

The following discussion uses multiple interviews to reconstruct the history of the program and its process of implementation.
While the mayor was running for office, one of his campaign consultants suggested that he promise to plant a million more trees in Los Angeles for their environmental benefits. As Villaraigosa was committed to improving the city's environment, this seemed like a good program to add to his other strategies. At the time, it did not seem like a difficult thing to accomplish and would yield important benefits to the city (A. Swiller, personal communication, December 10, 2007).

Shortly after coming into office in 2006, the mayor assigned the development of the MTLA program to one of his appointed public works commissioners. The commissioner contracted with Greg McPherson at CUFR for a canopy cover analysis, which also included mapping the distribution of trees in the city, the potential of different council districts for more trees (reflecting land use types, urban densities, and income), and the potential value for environmental benefits of planting a million more trees. Among other findings, the analysis showed that lowincome communities of color had the least canopy cover and often the highest population densities. Tree canopy correlated strongly with affluence and land use in the city as single-family neighborhoods had more trees-and more room for more trees-than neighborhoods that were more densely populated and contained multiple family dwellings. Neighborhoods with multiple family dwellings tend not only to have narrower planting strips (and thus less room for street trees), but also many less, and much smaller, yards, and so less room for trees on the parcels. The outcome was that council districts with lower-income residents of color tended to have lower tree canopy cover (McPherson and others 2008). One of the program's explicit missions was to help redress this inequality. Figure 3 shows the canopy cover by ethnic group in Los Angeles. Figure 4 shows the canopy hectares per council district, and Fig. 5 shows the canopy cover per council district with incomes.

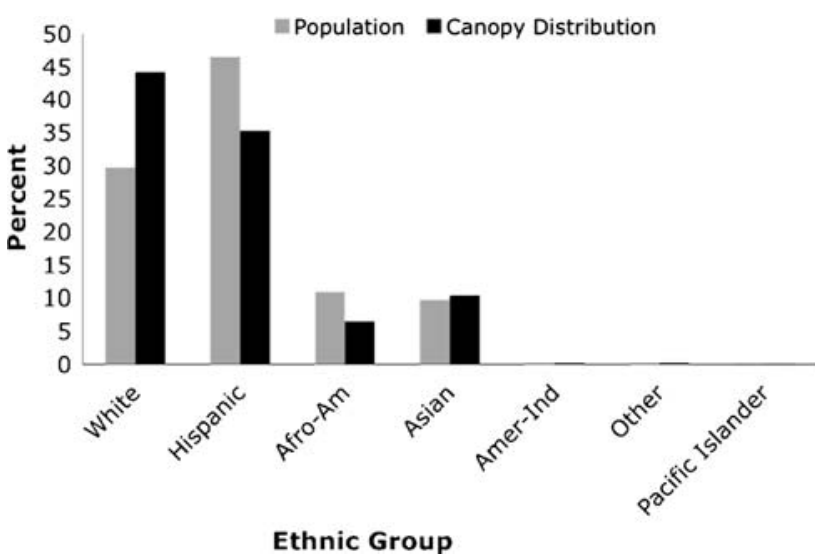

Fig. 3 Canopy cover per ethnic group 


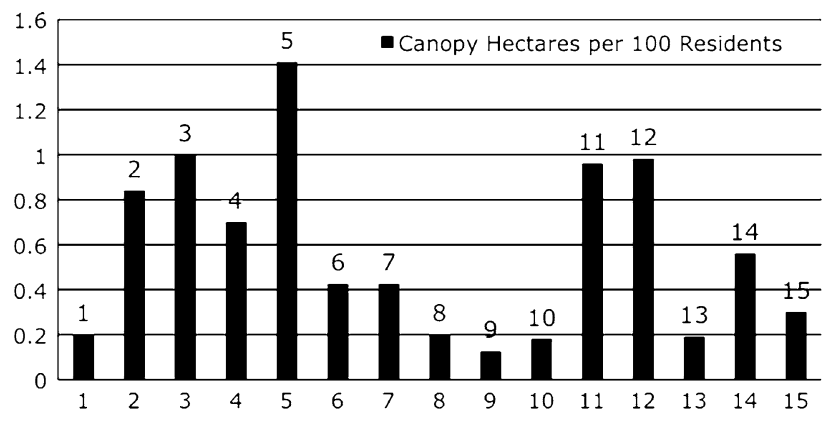

Fig. 4 Canopy hectares per 100 residents by council district

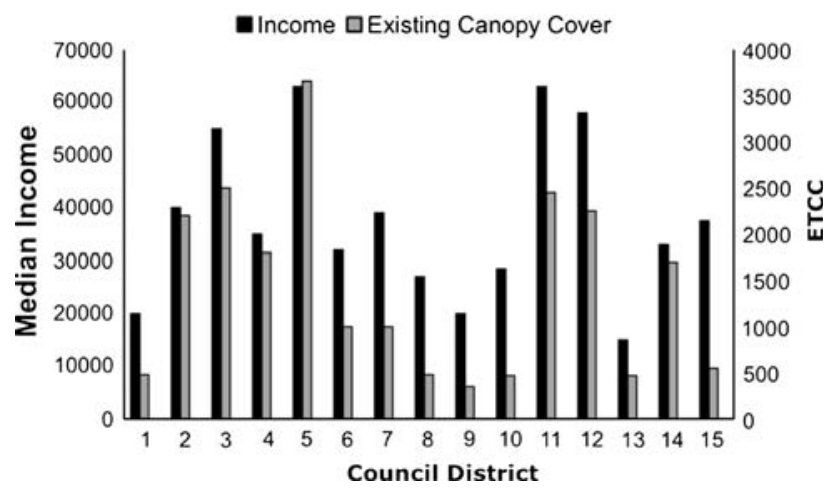

Fig. 5 Income and canopy cover

To create the program, the commissioner reached out to other city agencies and departments that could contribute to this effort to solicit their expert participation (e.g., the Urban Forestry Division of the Public Works' Department of Transportation, the Planning Department, and the Los Angeles Department of Water and Power (LADWP)) and to attempt to build interagency collaboration for a program that would potentially cut across many agencies. In addition, the commissioner invited the existing tree-planting nonprofit organizations to participate. A steering committee representing the departments and agencies and the major stakeholders in the city (including academic advisors) was created. A plan was developed under strict time schedules (about 3 months) as the mayor expected a million trees to be planted in his first term. Owing to the lack of city personnel and funding, the plan relied on the major tree-planting environmental organizations of the city to carry out the bulk of the program, creating a public-private partnership. In addition, a Million Tree Foundation was set up to raise funds for the program. The foundation was initially located in Community Partners, a foundation that hosts incubator foundations and nonprofits. The plan relied on a coproduction model, with the city piloting and coordinating the network of tree-planting nonprofits and agencies, which themselves represented a diverse set of expertise, missions, and approaches. Such organizational structures, with governmental agencies acting to coordinate
Weak mayoral system appointed commissions agency \& department heads

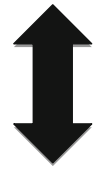

Multiple stakeholders: donors


Agency \& department civil servants

diverse business interests CBOs \& nonprofit funders neighborhood councils concerned citizens

Fig. 6 Los Angeles institutional and civic context for Million Tree Program

complex networks of public/private partners, have become more common as governmental funding has declined, in contrast to the city itself taking on and implementing new programs (Jessop 1999; Salamon 2002). Figure 6 illustrates the political context of the city of Los Angeles within which the program was created.

The coproduction approach to planting more trees in Los Angeles, as stated, relied on the existing tree-planting organizations of the city. Tree-planting nonprofits in Los Angeles range in size and capacity. They have different constituents and conduct tree planting for different institutionally specific purposes. For example, Hollywood Beautification Team has an emphasis on community capacity building, physical improvements, and job creation; North East Trees has a neighborhood-level ecosystem services restoration emphasis, building small-scale projects such as stream day-lighting and bioswales for stormwater interception in streets; Korean Youth and Community Center develops programs aimed toward recent immigrants and economically disadvantaged youths and their families who have experienced adjustment difficulties, and tree planting is used to improve neighborhoods where there are substantial numbers of Korean immigrants; the Los Angeles Conservation Corps is a job-training nonprofit that employs young people to provide conservation services for government agencies and private contract sponsors; and TreePeople has been planting trees since the early 1980 s to promote integrated watershed management practices through education, planting projects, policy development, and research. Each of these is self-organizing and self-reproducing and becoming increasingly interdependent in their involvement with the MTLA program, exhibiting the characteristics pointed out by Jessop (1994).

Each of the organizations brought strengths to the MTLA initiative and expectations about their roles based on their own institutional missions. For example, TreePeople expressed the desire to run the MTLA program, based on the 
organization's decades of experience in planting trees in the Los Angeles area and its ability to mobilize volunteers. North East Trees had hoped to provide design and planning direction to the program, based on its expertise in building ecosystem services-oriented projects in the city. Hollywood Beautification had expectations about employing more youths at risk and supplying labor to the initiative. But the city-whose needs were expressed by the public works commissioner-saw the nonprofits as providing the labor to plant the trees by council district. The commissioner's aim was to try to ensure consistency among the groups and similarity in approach so that the program would be uniformly implemented throughout the city. This entailed asking each of the nonprofits to accept the city-established processes, procedures, and priorities and to modify their own long-standing programs. The planting plan was therefore tersely negotiated with the nonprofit organizations as it required them to accept a new role: planting trees for the city's program, in the council districts determined by the city. Cooperating meant that planting the trees for MTLA blurred the distinctions between the nonprofits and the city, raising the question of whether the trees being planted in the neighborhoods were part of the NGOs' programs or MTLA's. This situation challenged the ability of the NGOs to raise funds for their own tree-planting programs and to maintain their own individual identities, as they became subsumed into the city MTLA initiative.

These conditions, in exchange for a fee per planted tree (fees that were predominantly paid for by the LADWP, building on LADWP's existing tree giveaway program), were grudgingly accepted by most of the organizations, which realized that they had little choice but to accept the city's conditions or not participate in the program at all. TreePeople withdrew from participating in neighborhood tree planting for MTLA and developed a separate arrangement with the Recreation and Parks Department to plant only park trees. TreePeople determined that it did not want its own long-standing volunteer-based neighborhood treeplanting program to be confused with MTLA's program, and it did not want to be confined to planting in the council districts chosen for the organization by MTLA (A. Lipkis, personal communication, July 17, 2007).

The MTLA program was launched with a big treeplanting and giveaway event in a park in East Los Angeles, a low-income Latino part of the city, in September 2007, not a year into the program's development. All the nonprofits were present, but there was already deep concern about the future of the program, as was confided to the author by one of the nonprofits at the event itself. The mayor had pledged to help raise funds necessary for the program but had not done so by then, thereby creating a situation in which the staff time of the participating nonprofits could not be compensated in the short term
(D. Bure, personal communication, July 30, 2007, no longer with the organization; L. Smith, June 6, 2007, no longer with the organization). It appeared that little or no new resources to implement the program were going to be forthcoming in a timely manner. Tree-planting organizations were faced with deficits in their budgets. In addition, no city agencies had diverted any of their budgets toward this effort. The Mayor's Office, concerned with the apparently slow start of the program-a million trees were to be planted in his first administration-and the unhappiness of the participants, pulled the program out of Public Works and sequestered it in the Mayor's Office (A. Swiller, personal communication, December 10, 2007). A longtime trusted aid was given the responsibility to make the program work (P. Daniels, personal communication, March 16, 2007; C. Espinosa, personal communication, December 16, 2007; H. Morris-Irvin, personal communication, December 16, 2007; K. Burn Roy, personal communication, July 10, 2007; A. Swiller, personal communication, December 10, 2007).

Several changes occurred. The number of trees to be planted in the mayor's first term was lowered, acknowledging that it would be nearly impossible to plant a million trees in four years. There was not enough funding to support the effort of the nonprofits that would have been required, nonprofit capacity was insufficient to handle that number of trees, and outreach to the public would have been an enormous undertaking. While this was certainly known by the Public Works commissioner who was charged with developing the program, the political reality at the time was that the mayor would not have been receptive to such a message, and therefore the program had to take on unrealistic deadlines (P. Daniels, personal communication, March 16, 2007). Furthermore, there had been several critical newspaper articles about the program, which pointed out the unrealistic numbers of trees to be planted in too short a period of time, the lack of funds for maintenance, that small seedlings had been distributed and counted as trees, and so forth. The mayor and his advisors were concerned about the negative press (A. Swiller, personal communication, December 10, 2007).

Finally, in the Mayor's Office, there was a gradual recognition that the program was too ambitious to be accomplished in a first term: planting a million more trees in the city would take much longer, would require a much greater investment in long-term maintenance than was initially anticipated, and would require additional organizational capacity and funding. Therefore, for the program to be successful, it would have to be implemented over 7-8 years (P. Daniels, personal communication, March 16, 2007; L. Sarno, meeting, July 30, 2008). While the public works commissioner's task force that assisted in developing the initial plan raised a number of questions about the plan's 
timeline and deployment, there was little choice but to go forward anyway because of pressure from the Mayor's Office to succeed in the mayor's first term. When the implementation took longer than the Mayor's Office felt was appropriate, and there was discontent because of lack of reimbursements, the public works commissioner was seen as the problem, rather than the problem being political pressures from a mayor needing to live up to his campaign promises, coupled with insufficient funding.

The program is now in the Mayor's Office, which has clearly defined it as a project of the mayor. The MTLA director coordinates and directs the program, which is organized as a network of moving parts with nonprofit partners, various city and state partners, and numerous funding sources (some with specific strings attached). This organizational structure reflects the fiscal and time constraints that Los Angeles faced in setting up a new program. There were also political constraints as it would have been politically damaging for the mayor not to rely on existing organizations that had established a track record in tree planting.

\section{How the Program Is Organized}

The Million Tree Foundation (a nonprofit 501c3) was created, as previously mentioned, to receive private donations to support the program. This foundation now lies in the Department of Public Works (DPW), the original home of the MTLA program, where there is much greater control by the Mayor's Office and less transparency. As a project of Community Partners, reporting was mandatory and annual because of the rules governing nonprofit organizations in the state of California. Other agencies also involved in planting trees for million-tree initiatives included the Community Redevelopment Agency and the Port of Los Angeles. In Los Angeles, the Department of Public Works, Bureau of Street Services, Urban Forestry Division is responsible for ongoing street tree maintenance. (Urban Forestry is responsible for pruning trees and removing dead or diseased trees. Pruning cycles have increased greatly with budget cuts to the department, and the department is largely involved in inspections, not implementation.) As part of its longstanding programs, DPW has established a list of trees that can be planted in the city's median strips and specifies a range of acceptable trees, depending on the size of the median strip. The division requires the approval of the homeowner for a tree to be planted and the agreement from the homeowner that he or she will water and maintain the tree for 5 years.

Nonprofit partners plant the new street trees. In accordance with their assigned council district boundaries, they go door to door to solicit participation in the program. This involves obtaining permission to plant slips from property owners or residents for each new street tree that is to be planted in the median strip in front of the property. Each nonprofit then plants the trees and attempts to maintain them the first year, contingent on funding for watering and having a watering truck. The planting program itself has no maintenance funds. The success rate in obtaining permission to plant slips is highly variable among the groups and the neighborhoods. This is because each nonprofit has a different approach to obtaining permission-to-plant slips, with some of them going door to door, leaving door hangers announcing the program; some knocking on doors; some using the mail; and some using a combination of these techniques. (We learned about this only through interviews and could not verify the information as there is no publicly available database that lists each nonprofit's number of trees planted and success rate at getting permission to plant slips.) Once the nonprofit has obtained the permission to plant, the Urban Forestry Division is responsible for tagging the specific trees that will be planted at participating nurseries. The Urban Forestry Division also inspects the site where the tree is to be planted and the planting itself to ensure that the tree is in the appropriate location and well planted. Finally, the LADWP, a municipally owned utility, funds the provision of the majority of the trees under an existing program to reduce the urban heat island. LADWP will also provide trees free to residents who request them (an online course is required).

More recently, the program has also started planting trees in public median strips near schools and areas with little urban vegetation and heavily impacted by traffic. The planting in public (nonresidential) median strips does not require owner permission but does require extensive coordination with the Bureau of Street Services, the local council district representative, and the relevant stakeholders such as adjacent public schools or businesses. The MTLA director explained that these areas were chosen opportunistically for their location near schools in disadvantaged neighborhoods (L. Sarno, meeting, July 30, 2008). This planting is not part of the negotiated agreements with the nonprofits but steps out of these agreements to partner with other groups and organizations in the neighborhoods.

For the tree supply side of the program, the director of MTLA decided that one of the tree-planting partners, the Los Angeles Conservation Corps (LACC), would be the city's primary contractor with LADWP's Trees for a Green Los Angeles Program, the municipal utility's residential program mentioned earlier, to streamline the program. Each of the other groups (Hollywood Beautification Team, Korean Youth and Community Center, and North East Trees) are subcontrators to LACC, simplifying the supply side but causing some tension between LACC and the other nonprofits over leadership and money. 


\section{Funding Sources}

Long-promised funding began to trickle in, including a large settlement grant dedicated to the program from the regional air quality management district. In 2007, the Air Quality Management District (AQMD), LADWP, and the DPW entered into an interagency agreement wherein the AQMD provided \$1 million to the DPW for the Million Tree Foundation to use in the implementation of the MTLA initiative. The DPW put the money into its "gift fund" so that it could be provided to the Million Tree Foundation. The DPW was also to receive \$2.4 million from the AQMD to assist in the implementation of the program, including administering, planning, and planting 4,700 15-gallon or larger trees on public property, right-of-ways, or easements to shade residential homes and businesses. Of course, planting on easements to shade residential homes and businesses, if adjacent to those properties, requires consent from the resident or business owner to agree to water the trees for 5 years. The trees were to be planted in the areas of the city identified by the U.S. Department of Agriculture McPherson report (McPherson and others 2008) as lacking canopy cover and where more trees could be planted. The agreement also specified that the trees must have low ozone-forming potential and that DPW shall be responsible for the long-term maintenance of all trees planted pursuant to the agreement. All the carbon dioxide benefits, energy efficiency, and other environmental benefits associated with the trees planted are to accrue to the LADWP, the municipal utility. The reason for this specific arrangement is that the DWP is reliant on coal-fired power plants for most of its power. Planting trees in Los Angeles may become an offset for greenhouse gas emissions for LADWP in the future because California is creating a cap and trade program. In addition, the foundation has received pledges for nearly $\$ 1$ million more (source unspecified), which will be dedicated to long-term maintenance (L. Sarno, meeting, July 30, 2008). Figure 7 shows the blended funding sources were able to discover, though there may be others as well.

The Los Angeles program, for financial and practical reasons, also relies significantly on homeowners to plant free LADWP trees in their yards to increase canopy cover. According to the current MTLA director, 700,000 of the million trees will need to be planted on private property (L. Sarno, meeting, July 30, 2008). Private property in the city has the most potential for tree planting because it has the most room for additional trees. All street tree planting, even by private property owners, requires the same permit process outlined earlier for the nonprofit organizations, including a commitment to water the trees for the first 5 years. Trees may only be from the city-approved list and

\begin{tabular}{ll}
$\begin{array}{l}\text { Government funding } \\
\begin{array}{l}\text { Federal - community } \\
\text { development block grant } \\
\text { State - forestry or other }\end{array}\end{array}$ & $\begin{array}{l}\text { Private funding } \\
\text { Corporate e.g., Home Depot } \\
\text { Business improvement } \\
\text { districts }\end{array}$ \\
$\begin{array}{l}\text { Regional e.g., So Cal Air } \\
\text { Quality Management District } \\
\begin{array}{l}\text { City - local utilities, park } \\
\text { departments, other agencies }\end{array}\end{array}$ & Homeowner associations \\
\hline
\end{tabular}

Fig. 7 Blended funding for tree planting

must approved by the Urban Forestry Division to ensure that the tree is of the right size for the planting location. There is some indication from other cities, however, that reliance on private property owners to plant trees tends to increase tree canopy cover disparities in cities as more affluent residents are more likely to be homeowners and willing to plant and maintain trees on their properties (Heynan and others 2006). In Los Angeles, such a disparity already exists, and though private homeowners planting more trees will increase canopy cover, it may simply exacerbate the already substantial inequality in canopy cover.

\section{Socioeconomic Factors}

Beyond the complicated permit process to plant a street tree, which involves eight distinct steps and sign-offs by city departments, there is a perception that canopy cover makes it easier for criminals to hide, and this idea is strongly supported by the police department in Los Angeles, which relies heavily on helicopters in its policing (M. Bartlett, personal communication, August 17, 2007; D. Bure, personal communication, July 30, 2007; L. Sarno, meeting, July 30 , 2008). Researchers were told that this perception creates reluctance in certain neighborhoods to agree to plant-or have planted-additional street trees. Moreover, some immigrants are reluctant to fill out the form for street tree planting as it requires a signature. In addition, such a form is ideally signed by the property owner, who may not be aware of the program or who may be an absentee landlord and not committed to watering a tree for 5 years and/or not interested in participating. This situation is more prevalent in multiple-family neighborhoods, where tree canopy cover is lower to begin with (D. Bure, personal communication, July 30, 2007; L. Sarno, personal communication, July 30, 2008). Still, it is important to note that as of this writing, over 175,000 trees have been planted in the city by the diverse partners since the inception of the program. 


\section{Discussion}

The MTLA planting program began as a campaign promise to distinguish Mayor Villaraigosa as a green-oriented candidate from his opponent. Tree planting, for him, was a strategy to improve the environment of the city, including air quality. It was suggested to him by a campaign consultant, who knew of Villaraigosa's interest in the environment (A. Swiller, personal communication, December 10, 2008).

The program relies on existing tree-planting nonprofit organizations that have experience in planting trees. The program itself is located in the Mayor's Office, but its nonprofit foundation, which funds portions of the program, is located in the DPW. Tree stock is provided through funding by the municipal utility, the LADWP. Funding comes from multiple sources, including private, federal, state, and city sources.

This kind of complexity is one result of the fiscal constraints on city budgets, including those imposed by the 1978 passage of Proposition 13 (dramatically cutting local property taxes), followed by Proposition 218 in the mid-1990s, making raising new revenues very difficult in California (Pincetl 1999; Schrag 1999, 2008). New York City (before the recent economic downturn), by way of comparison, was able to set aside $\$ 400$ million for the program, administered by the Department of Parks and Recreation. The department planned to implement the program over 10 years and hired 40 arborists. More would have been hired if they had been available. New York City is not subject to the same kinds of regulatory constraints on raising public funds because there have been no state referenda limiting property taxes and there is no two-thirds majority requirement for other tax increases, in contrast to California. Additional money has been raised through the private sector as well, reflecting the well-known, historic philanthropic depth of New York City. At the same time, New York City, too, relies on partnerships, including community-based and nonprofit groups; city, state, and federal agencies; corporations and small businesses; developers, architects, and landscape architects; private property owners; and, as the Web site states, all New Yorkers. The differences between Los Angeles and New York City illustrate how similar programs, with similar intents, may be implemented in substantially different ways because of local institutional and historic differences.

The collaborative approach to implementation is an example of what Jessop (1998) has described as an emergent process of governance through negotiation, compromise, and network building toward a common goal, involving heterarchic organizations in a complex web of interrelationships. Negotiation first by the commissioner of public works, then the director of the program in the Mayor's Office, with five nonprofit organizations and multiple city, regional, and state agencies, was directed toward a joint project: planting a million trees. This led to an interorganizational coincidence of interests, with tangled hierarchies and parallel power networks. Tangled hierarchies exist among the tree-planting groups themselves and among the different city agencies, too.

Urban tree planting is often a coproduction by government in collaboration with private individuals, businesses, and nonprofit organizations. This coproduction owes to several factors: to achieve high levels of canopy cover, cities need private property owners to plant trees on their properties as there is not enough public land to achieve the desired numbers of trees. Such programs also build on neighborhood beautification and tree-planting programs that have been the domain of nonprofit organizations (see programs by People for Parks, People and Parks, or Project for Public Spaces). Some cities, such as Houston, rely entirely on philanthropic and private-sector planting. These coproductions show the varied cultures of civic involvement that exist in the country. Researchers know little about the outcomes of these different approaches at this time because such programs are relatively young and will take up to a decade to execute.

In contrast to other kinds of urban environmental infrastructure (sewage sanitation pipes, electrical wires, cable TV), trees are living entities requiring care on a regular basis throughout the year. Living things are subject to different influences than gray infrastructure: disease, lack of sufficient nutrients or water, vagueries in climate, and human neglect or vandalism. It may be that green infrastructure necessarily involves nonprofit organizations and city dwellers as stewards because most cities do not have sufficient numbers of employees, or funds, to maintain this kind of living infrastructure. Though this might not mean daily, weekly, or even monthly tending, if trees are deciduous, there will be seasonal cleanup of leaves; if trees shade existing plantings, residents will have to change the plants so they will survive a shaded exposure; and finally, for cities with little or no funds for regular tree trimming, residents may incur the costs of trimming the trees in front of their properties, a potentially costly proposition.

\section{Conclusion}

Municipal forests consist of street trees, park trees, and trees planted on private property. Planting and maintaining trees in many U.S. cities involves multiple partners and multiple agencies. Partners include property owners, nonprofits, and local agencies: parks departments and public works and/or transportation departments, redevelopment agencies, special purpose agencies, and regional agencies such as air districts. The program in Los Angeles exemplifies a partnership approach and can be described as a coproduction, in which 
the Mayor's Office serves to control, direct, and supervise the participation of differentiated public and private entities, dispersed across the city.

The specific origins of MTLA as a campaign promise, its heterachic structure-overlapping, multiple-centered participants with mixed ascendancy and divergent but coexistent patterns of cooperation-and complex financing, are a result of local conditions that have been discussed previously. Bhaskar and Danermark (2006) argue that critical realism provides a platform for understanding as it acknowledges that there might be causal powers at different levels of reality. Our example illustrates what Bhaskar and Danermark characterize as a "laminated" system, in which explanations involve mechanisms at several levels. How robust this laminated collaborative governance approach to planting and maintaining the new urban forest will be is yet to be ascertained. Maintaining the participation of what Jessop (1998, p 30) describes as "disparate entities that may have their own complex operational logic" makes it difficult to control collaboration. Some of the nonprofits among the treeplanting partners are smaller and more idiosyncratic, whereas others are larger and run more professionally; these differences make each organization unique, and bringing them together cooperatively is challenging because there are a multiplicity of intersecting discourses and practices, each with its own links to economic relations and civil society (Jessop 1990).

Governance is not the same as government; the former includes actors such as communities, businesses, and nonprofit organizations. As González and Healy (2005) have shown, governance processes come to be understood as variable and contingent in their focus, forms, and modes, although all kinds of wider forces can be identified as shaping specific institutional space. Governance approaches involve strategic partners to achieve specific results-partnerships that may or may not be enduring. Governance relationships are mutually constitutive and require cooperation and collaboration. Key to the shape of the form of governance are the political-economic relationships that the institutions embody and how the relationships shape identities, actions, and outcomes. The Mayor's Office in Los Angeles depends on the nonprofit sector to implement the program; it also funds its implementation and derives legitimacy from the program's deployment. At the same time, city funding supports the diverse group of participating nonprofits-they have become interdependent, shaping each other in the process.

The state also is not a homogenous force but, quoting Jessop (as cited in González and Healy 2005, pp 2057-2058), "a specific institutional [ensemble] with multiple boundaries." Given the current structure and location of the Los Angeles program, the future of the program is uncertain. Being a project of the mayor means that the program could be eliminated by the next mayor or merged into a traditional infrastructure department or even entirely spun off to the nonprofit sector. The state changes with different leadership priorities as well as funding and public support for different programs and investments.

The MTLA program has thus far been creative and inventive in translating a mayoral dream into reality. Yet existing hurdles about long-term management and maintenance, climate appropriateness of the trees being planted, redressing canopy inequalities in disadvantaged areas, and how to foster stewardship of this new infrastructure loom on the horizon.

Acknowledgments Research for this article was funded by the National Science Foundation Humans and Social Dimensions grant 0624177 and by an EPA G2006-STAR-H1Communities and the Built Environment grant. Special thanks to Thomas Gillespie for his thoughtful and encouraging comments and to Alex Marlantes for his figures on income and canopy cover. Thank you also to my Co-Pi's Diane Pataki, Sassan Saatchi, Jean Daniel Saphores, and, again, Thomas Gillespie. Thank you to careful reviewers, whose comments greatly improved this article. All interviews were conducted according to a UCLA Institutional Review Board-approved interview instrument, and interviewees signed consent forms. Each interview was also transcribed and sent to the interviewee for corrections, redactions, and additions.

Open Access This article is distributed under the terms of the Creative Commons Attribution Noncommercial License which permits any noncommercial use, distribution, and reproduction in any medium, provided the original author(s) and source are credited.

\section{References}

Alberti M, Susskind L (1996) Managing urban sustainability: an introduction to the special issue. Environmental Impact Assessment 16:213-221

Attwell K (2000) Urban land resources and urban planting-case studies from Denmark. Landscape and Urban Planning 52: $145-163$

Bhaskar R, Danermark B (2006) Metatheory, interdisciplinarity and disability research: a critical realist perspective. Scandinavian Journal of Disability Research 8:278-297

Brack CL (2002) Pollution mitigation and carbon sequestration by an urban forest. Environmental Pollution 116:S195-S200

California Energy Commission (2006) Our changing climate: assessing the risks to California. Report 500-2006-077. California Energy Commission, Sacramento

Cohen JE (2003) Human population: the next half century. Science 302:1172-1175

Coles RW, Bussey SC (2000) Urban forest landscapes in the UK-progressing the social agenda. Landscape and Urban Planning 52:181-188

Drummond I, Marsden T (1999) The condition of sustainability. Routledge, London, $242 \mathrm{pp}$

Fulton W, Pendall DR, Nguyen M, Harrison A (2001) Who sprawls most? How growth patterns differ across the U.S. Brookings Institution, Washington, DC

Geoghegan J, Wainger LA, Bockstael NE (1997) Spatial landscape indices in a hedonic framework: an ecological economics analysis using GIS. Ecological Economics 23:251-264 
González S, Healy P (2005) A sociological institutionalist approach to the study of innovation in governance capacity. Urban Studies 42:2055-2069

Harden B (2005) Out west, a paradox: densely packed sprawl. Washington Post, August 11, p A01

Heynan N, Perkins HA, Roy P (2006) The political ecology of uneven urban green space: the impact of political economy on race and ethnicity in producing environmental inequality in Milwaukee. Urban Affairs Review 42:3-25

Iverson LR, Cook EA (2000) Urban forest cover of the Chicago region and its relation to household density and income. Urban Ecosystems 4:1083-8155

Jessop B (1990) State theory: putting the capitalist state in its place. Polity Press, Cambridge, 413 pp

Jessop B (1994) The regulation approach, governance and postFordism: alternative perspectives on economic and political change. Economy and Society 24:307-333

Jessop B (1998) The rise of governance and the risks of failure: the case of economic development. International Social Science Journal 50:29-45

Jessop B (1999) The governance of complexity and the complexity of governance: preliminary remarks on some problems and limits of economic guidance. Department of Sociology, Lancaster University, Lancaster

Jessop B (2000) Good governance and the urban question: on managing the contradictions of liberalism. Department of Sociology. Lancaster University, Lancaster

Jordon A, Rudiger K, Wurzel W, Zito AR (2003) New instruments of environmental governance: patterns and pathways of change. Environmental Politics 12:1-24

Landsberg HE (1981) The urban climate. Academic Press, London, $275 \mathrm{pp}$

Li F, Wang R, Paulussen J, Liu X (2005) Comprehensive concept planning of urban greening based on ecological principles: a case study in Beijing, China. Journal of Landscape Planning 72: 325-336

Mansfield C, Pattanayak SK, McDow W, McDonald R, Halpin P (2005) Shades of green: measuring the value of urban forests in the housing market. Journal of Forest Economics 11:177-199

McPherson EG, Rowntree RA (1993) Energy conservation potential of urban tree planting. Journal of Arboriculture 19:321-331

McPherson EG, Scot KI, Simpson JR (1999) Benefit-cost analysis of Modesto's municipal urban forest. Journal of Arboriculture 25: 235-248

McPherson EG, Simpson JR, Xiao Q, Wu C (2008) Los Angeles Million Tree canopy cover assessment. General technical report
PSWGTR-207. Pacific Southwest Research Station, Forest Service, U.S. Department of Agriculture, Albany, p 53

Miller R, Shapiro H, Hilding-Hamann KE (2007) Learning spaces in Europe 2020: a rigorous imagining exercise "School's over: the rise of learning spaces." Danish Technological Institute, Future learning in the knowledge based society in Europe, Information and Communication Technology (ICT) Contract No 1505422006, FISC DK, p 94

Moll G, Ebenreck S (1989) Shading our cities. Island Press, Washington, DC, $333 \mathrm{pp}$

Nowak DJ, Hoehn RE III, Crane DE, Stevens JC, Walton JT (2006a) Assessing urban forest effects and values: Washington, D.C'.s urban forest. Resource bulletin NRS-1. Northern Research Station, Forest Service, U.S. Department of Agriculture, Newtown Square

Nowak DJ, Hoehn RE III, Crane DE, Stevens JC, Walton JT (2006b) Assessing urban forest effects and values: Casper's urban forest. Resource bulletin NRS-4. Northern Research Station, Forest Service, U.S. Department of Agriculture, Newtown Square

Nowak DJ, Crane DE, Stevens JC (2006c) Air pollution removal by urban trees and shrubs in the United States. Urban Forestry and Urban Greening 4:115-123

Pierre J (2000) Introduction: understanding governance. In: Pierre J (ed) Debating governance. Oxford University Press, Oxford, pp 1-10

Pincetl S (1999) Transforming California: a political history of land use in the state. Johns Hopkins University Press, Baltimore, $372 \mathrm{pp}$

Rowntree RA, Nowak DJ (1991) Quantifying the role of urban forests in removing atmospheric carbon dioxide. Journal of Arboriculture 17:269-275

Salamon LM (2002) The tools of government: a guide to the new governance. Oxford University Press, New York, $669 \mathrm{pp}$

Sayer A (2000) Realism and social science. SAGE, London, 211 pp

Schoenherr AA (1992) A natural history of California. University of California Press, Berkeley, 804 pp

Schrag P (1999) Paradise lost: California's experience, America's future. University of California Press, Berkeley, $341 \mathrm{pp}$

Schrag P (2008) Proposition 13 at 30: what a mess it has made. Sacramento Bee, June 4, p B9

Scott KI, McPherson EJ, Simpson JR (1998) Air pollutant uptake by Sacramento's urban forest. Journal of Arboriculture 24:224-234

Tyrvainen L (1997) The amenity value of the urban forest: an application of the hedonic pricing method. Landscape and Urban Planning 37:211-222 